\title{
METHOD OF STRATEGIC PLANNING AND MANAGEMENT DECISION-MAKING CONSIDERING THE LIFE CYCLE THEORY
}

\author{
Tetiana Kniazieva ${ }^{1}$, Yuriy Kolbushkin ${ }^{2}$, Sergiy Smerichevskiy ${ }^{3}$ \\ National Aviation University, Ukraine
}

\begin{abstract}
The subject of the study is a set of theoretical and methodological aspects of development strategy formed for objects (country, region, branch, enterprise) on the basis of the life cycles theory under the external environment uncertainty. The methodology of strategic planning under the external environment uncertainty with the consideration of the life cycle theory includes: the definition of key criteria for assessing the product lifecycle, the definition of the limits scope for the solvable problem, the definition of parameters of models stability, the formation of models for analysis, setting the problem under uncertainty, the mechanism of step-by-step adjustment, and effectiveness assessment of strategic decisions based on strategies, the algorithm for the integrated assessment of the strategies effectiveness taking into account the uncertainty factors. Strategic planning is not characterized by temporal intervals but by a set of strategies, each of which is determined by the ways of achieving the main object objectives. For a rapid analysis of the product life cycle, the external indicators are used, such as: the growth rate of the product market, the relative growth rate of the product (compared to the growth rate of the entire market of the region or country), the firm market share, the firm relative market share (compared to the market share of leading competitor), and internal indicators, such as: the dynamics of enterprise revenue by product, the dynamics of company profits by product, the dynamics of enterprise profitability by product, the dynamics of enterprise investment. For each indicator that describes the enterprise performance, the directions of change are taken: $\alpha$-growth, const - constant or $\beta$-decrease. The methodology involves a certain sequence of studying the product life cycle in retrospect and at the current moment, then the modelling and development of options for short- and long-term strategies implementation are made. Results of the survey are to substantiate the methodology of strategic planning under conditions of external environment uncertainty with the consideration of the life cycle theory. Practical implications: the possibilities of using life-cycle models allow: 1. reasonably predicting sales and plan production program; 2 . determining the basic strategies at different stages of development; 3 . determining the sequence of stages of enterprise development; 4. ensuring harmonious interaction of organizational characteristics with the external environment factors that influence the process of organizational development. Increasing the sustainability of the organization's development can be achieved by re-establishment of dynamic changes in the plan in terms of using effective methods for forecasting with the consideration of the life cycle theory. It is necessary to take into account the interconnection between all levels of life cycles: industry, technology, enterprises, product; ensuring the competitive advantage of the organization. Using the theory of optimal solutions making in uncertain conditions under the analysis of long-term projects allows transferring qualitative factors into quantitative indicators that can be used in the future to bring investment projects to the same kind and choose the best. In conditions of increased uncertainty of the external environment, it is necessary to develop the theory of enterprise management, taking into account its life cycle, as well as the life cycle of its separate elements and processes at all levels. Combination of strategic management with the life cycles theory will increase the objectivity and effectiveness of taken management decisions. The accounting of the organization life cycles in strategic planning allows choosing an effective strategy.
\end{abstract}

Key words: life cycle, portfolio analysis, strategic areas of management, financial results, management decisions efficiency.

\section{JEL Classification: D15, E32, L1}

\footnotetext{
Corresponding author:

${ }^{1}$ Department of Marketing, National Aviation University.

E-mail: tatiana.kniazieva2017@gmail.com

${ }^{2}$ Department of Marketing, National Aviation University.

E-mail:kup@gmail.com

${ }^{3}$ Department of Marketing, National Aviation University.

E-mail: s_f_smerichevsky@ukr.net
} 


\section{Introduction}

It is important to note a significant contribution to the development of the strategic planning theory and practice of such foreign experts as I. Ansoff, M. Weber, H.-L. Gantt, M.-H. Mescon, F.-W. Taylor, H. Fayol and others; domestic scientists-economists: O. Amosha, V. Heiets, B. Danylyshyn, M. Dolyshnyi, M. Melnikova, A. Muzychenko, O. Povagny, etc. To the theme of life cycles theory, many works of domestic and foreign authors are devoted: I. K. Adizes, L. Greiner, D. Katz, R.-F. Kahn, H. Lippitt, T. Malaya, O. Minochkina, Yu. Shambel. Most of the work focuses either on the common use of the life cycles theory and forecasting or on the application of the life cycles theory in the system of strategic planning and management. At the same time, the issue of strategic planning integrated study of the life cycles theory and the uncontrolled external conditions accounting remain insufficiently studied despite a large number of works in this area. From the point of view of practical implementation among the most actual and complicated tasks, the following can be named: 1 . Application of the life cycles theory in quantitative prediction of the economic systems development. 2. Identification of factors that determine the stage of the system's lifecycle and key factors that influence the development of the system at each stage of the life cycle, management of the life cycle system. 3. Instruments for determining the stages of the development of the system life cycle. 4. Accounting for uncontrolled and controlled factors in the formation of a system development strategy based on the life cycle theory. 5. Adjustment of the life cycles of the system elements (for example, when forming an optimal market portfolio that consists of the organization strategic business units). The purpose of the research is to reason the strategic planning methodology under an undefined external environment with the consideration of the life cycle theory. The scientific novelty of the research is to improve strategic planning in conditions of undefined external environment taking into account the life cycle theory of the object that includes: the definition of key criteria for the product life cycle assessment, the definition of the scope of limits for the solvable problem, the definition of parameters of models stability, forming models for analysis, the mechanism of step-by-step adjustment and assessment of strategic decisions effectiveness on strategies. The methodology assumes a certain sequence of the product lifecycle study in retrospect and at the current moment. Then the shortand long-term strategies modelling and development of options for their implementation are made.

The life cycles theory has been applied in relation to different systems and processes: countries, regions, industries, types of activities, enterprises and organizations, technologies, strategic business units, manufactured products, etc. There are over 1.5 thousands of different types of economic life cycles of systems. Among the most famous are Greiner Growth Phases, Joseph Kitchin inventory cycles, Jaglar's machinery and equipment investment cycles, Kuznets Cycles, Kondratiev Cycles.

The following issues are considered in the research: the theoretical aspects of strategic planning and management at the modern stage are discussed, the necessity of taking into account the stages of life cycles in strategic planning is reasoned, method of strategic planning of the life cycle stages is improved, an algorithm of strategic planning under conditions of an indefinite external environment and accounting uncontrolled factors is formulated.

Economic history and modern economic practice indicate that the rise and fall of business activity at the mega- and macro-levels are largely conditioned by two factors: scientific discoveries in the production means; great (sharp) changes in the political superstructure and economic relations of the states.

The analysis of micro-level cyclic fluctuations is carried out on the basis of life cycle product models, the organization's life cycle, the technology life cycle, etc. From the practical point of view, the applicability of the life cycles theory in the strategic planning of business entities is especially interesting.

\section{Theoretical aspects of strategic planning and management at the present stage}

The modern concept of strategic management assumes the governance by various economic systems (country-region-company). As a result of the evolution of the corporate planning eras, when the management concepts were influenced by changes in production and the environment in the 60 s and 70 s of the XX century, the basis of strategic management was formed. Currently, the methods of strategic management are used by the government, the cities and regions administration, large corporations, state enterprises, various non-profit organizations. Strategic management methods allow using and developing the competitive advantages of the economic system in unstable external environments.

With large flows of information, a high degree of external environment uncertainty or variability, there is a need to systematize information throughout the life cycle of the analysed object. The effectiveness of implementing CALS-technologies for ordering, encoding, classifying, storing, and transmitting information over life cycle stages is highly appreciated.

Comprehensive accounting and information usage allow creating the necessary base for analysis, forecasting, and planning of the company's activity, increasing the validity of strategy development, revealing false strategies, making it possible to adjust the enterprise plans and budgets in time.

The effectiveness and the possible set of strategies depend on the stage of the object life cycle. The 
following can be pointed as the main life cycles stages: 1 - formation (creation, origin, emergence), 2 - development (intensive growth), 3 - stabilization (maturity), 4 - crisis (decline, aging, liquidation). For example, the enterprise features depending on the life cycle stage clearly demonstrate the difference in requirements for the strategies formation (Table 1.1). If on the first stages of the company's lifecycle flexibility and adaptation to changes are high, the company is able to modify and correct the strategy quickly, and then at the next stages, the high inertia of the existing organizational and management structure exists.

At the early stages of the company's development, there is a high probability of a bankruptcy over the internal weakness of the company in comparison with existing competitors, at the next stages, the probability of the crisis is determined by the degree of inertia to external changes. An example of the formation of basic strategies at each stage of the life cycle is given in Table 1.2.

\section{Reasons to consider life cycles stages in strategic planning}

When considering the life cycles theory, one operates the following concepts: development, sustainable development, organizational development, organizational changes, systems development laws, life cycle stages, etc. There are four main approaches for managing organization's development related to the theoretical description of the enterprise operation: firm's neoclassical, institutional, evolutionary and entrepreneurial theories.

Various aspects of the enterprise activity are the objects of attention of each of the listed theories. For example, the neoclassical theory considers an enterprise as a

Table 1.1

Features of the strategies formation at different stages of the company's lifecycle

\begin{tabular}{|c|c|c|c|c|c|}
\hline Stage Name & $\begin{array}{l}\text { Entrepreneurship } \\
\text { Stage }\end{array}$ & Collectivity Stage & $\begin{array}{l}\text { Formalization and } \\
\text { Management Stage }\end{array}$ & $\begin{array}{c}\text { Stage of Structure } \\
\text { Creation }\end{array}$ & Decline Stage \\
\hline Stage Feature & $\begin{array}{l}\text { Unclear goals, high } \\
\text { creative possibilities }\end{array}$ & $\begin{array}{l}\text { Informal } \\
\text { communication } \\
\text { and structure; high } \\
\text { commitment }\end{array}$ & $\begin{array}{l}\text { Rules formalization; } \\
\text { stable structure; } \\
\text { emphasis on } \\
\text { efficiency }\end{array}$ & $\begin{array}{l}\text { Structure complication; } \\
\text { decentralization; } \\
\text { diversified markets; } \\
\text { uniqueness }\end{array}$ & $\begin{array}{l}\text { High personnel turnover; } \\
\text { growing conflicts }\end{array}$ \\
\hline $\begin{array}{c}\text { Focus of Stage } \\
\text { Strategy }\end{array}$ & $\begin{array}{l}\text { The strategy is } \\
\text { aimed at: identifying } \\
\text { consumer needs, } \\
\text { survival, and } \\
\text { concentrated growth }\end{array}$ & $\begin{array}{l}\text { The strategy } \\
\text { is aimed at: } \\
\text { expanding the } \\
\text { contact audience, } \\
\text { integrated growth }\end{array}$ & $\begin{array}{l}\text { The strategy is aimed } \\
\text { at: conformity to the } \\
\text { external environment } \\
\text { and ongoing changes, } \\
\text { balanced growth, } \\
\text { image formation }\end{array}$ & $\begin{array}{l}\text { The strategy is aimed } \\
\text { at: the formation of } \\
\text { an optimal portfolio, } \\
\text { effective investments } \\
\text { redistribution, } \\
\text { coordination, social } \\
\text { factors, differentiated } \\
\text { growth }\end{array}$ & $\begin{array}{l}\text { The strategy is aimed } \\
\text { at: survival, resources } \\
\text { mobilization, search } \\
\text { for the ways and means } \\
\text { to resist the crisis, } \\
\text { elimination, harvesting, } \\
\text { costs reduction }\end{array}$ \\
\hline
\end{tabular}

Source: systematized by the authors taking into consideration (Chandler, 2015; Chaffee, 2011; Meier, 2015)

Table 1.2

Basic strategies at different stages of the lifecycle

\begin{tabular}{|c|c|c|}
\hline Lifecycle Stage & Strategies & Note \\
\hline $\begin{array}{c}\text { Creation and } \\
\text { development start }\end{array}$ & $\begin{array}{l}\text { Business strategies, market penetration strategy, and survival } \\
\text { strategy }\end{array}$ & $\begin{array}{l}\text { Capital attraction, production base forming, free } \\
\text { market segments identification, competitors fighting, } \\
\text { maximal risk }\end{array}$ \\
\hline Growth & $\begin{array}{l}\text { The increase of production strategy, range expanding } \\
\text { strategy, sales and profitability growth strategy, integration } \\
\text { strategy (market segment seizure) }\end{array}$ & $\begin{array}{l}\text { Additional capital attraction, production base } \\
\text { development, market infrastructure establishment, } \\
\text { profitability growth, own market segment definition, } \\
\text { average risk }\end{array}$ \\
\hline Stabilization & $\begin{array}{l}\text { Sustainable growth strategy, stability strategy, the strategy of } \\
\text { competitive position keeping (maintaining), the strategy of } \\
\text { keeping the achieved profit level, minimizing costs strategy, } \\
\text { conservative strategies }\end{array}$ & $\begin{array}{l}\text { The stable financial condition, organizational and } \\
\text { industrial structures are formed, communications in } \\
\text { the external environment are established }\end{array}$ \\
\hline Aging & $\begin{array}{l}\text { Loss-making practices eliminating strategy, over-the-counter } \\
\text { assets eliminating strategy. Reducing production volumes } \\
\text { strategy. Improving products, technology, business strategy. } \\
\text { Effective market portfolio formation strategy }\end{array}$ & $\begin{array}{l}\text { Fixed assets depreciation, product competitiveness } \\
\text { deterioration, lack of financial resources }\end{array}$ \\
\hline Renaissance & $\begin{array}{l}\text { Cost reduction strategy. Survival strategy. Unprofitable } \\
\text { directions elimination. Modernization of existing and } \\
\text { creation of new production }\end{array}$ & $\begin{array}{l}\text { Management strategy adjustment. Financial } \\
\text { resources involvement, new technologies search and } \\
\text { introduction, market positions restoration }\end{array}$ \\
\hline
\end{tabular}

Source: developed by the authors taking into account (Higgins, 1993; Kotler, 1991) 
"black box", which converse the output resources into products; institutional theory pays much attention to operating costs savings; evolutionary theory suggests that the goal of any organization should be the development of organizational features according to the environment variables; entrepreneurial theory studies the relationship between the entrepreneur and his business.

All this speaks about the variety of views on the process of managing the enterprise sustainable development. The main task of the research in the field of life cycles building and the main approaches to the management of enterprises development studying is to identify the key factors that determine the development process.

In conditions of increased external environment uncertainty, it is necessary to develop the enterprise management theory, taking into account its life cycle, as well as the life cycle of its separate elements and processes at all levels. The combination of strategic management with the life cycles theory will increase the objectivity and effectiveness of the management decisions taken. Accounting of organization life cycles in strategic planning allows choosing an effective strategy.

There are many different growth models of the enterprise (organization) and their classifications: Lifecycle models of Adizes; Stage models of Lippitt and Schmidt phases; evolutionary models (Grainer's Evolutionary models); transformation models (Transition models of Hofer, Charan, Christensen). The listed models are mostly symbolic, they do not contain the quantitative criteria for describing the life cycle stages, and the transition to the next stage is explained by the crisis in the system. The modern approach to build organization life cycle involves such qualitative indicators as intangible assets: a strong brand, knowledge and experience of key employees, relations with clients and partners, use of advanced technologies, etc.

The products, technology, and demand of life cycle accounting allow coordinating the enterprise products range with its production capacity, new technologies and market demand under strategic planning. The modern approach to the creation of the organization life cycle involves such qualitative indicators as intangible assets: strong brand, knowledge and experience of key employees, relations with clients and partners, use of advanced technologies, etc. Interest is the ratio of the different types of life cycles duration (Table 1.3).

Analysis of the life cycles types in the industry, demand, technology, enterprise (organization), product focuses on identity problems of the practical application of different types of life cycles.

As a result, a number of situations may be considered (Rumelt, 2014):

1) Industry, technology, enterprise (organization), and product - all of them are at one stage (for example, the stages of origin or growth, maturity, decline).

2) Stages of the industry, technology, enterprise (organization), and product are different. The main
Table 1.3

Alternative life cycle theories

\begin{tabular}{|c|c|c|}
\hline $\begin{array}{c}\text { Type of life } \\
\text { cycle }\end{array}$ & Characteristic & Duration \\
\hline Need & $\begin{array}{c}\text { The main condition for } \\
\text { the buyer appearance }\end{array}$ & Uncertain \\
\hline Demand & $\begin{array}{c}\text { Specific solution for } \\
\text { the need satisfaction } \\
\text { problem }\end{array}$ & Very long period \\
\hline Technology & $\begin{array}{c}\text { Scientific and technical } \\
\text { capabilities }\end{array}$ & Short period \\
\hline Product & $\begin{array}{c}\text { Product created with } \\
\text { using special technical } \\
\text { solutions }\end{array}$ & More short period \\
\hline Trade mark & $\begin{array}{c}\text { Name assigned by the } \\
\text { manufacturer to the } \\
\text { product }\end{array}$ & Long period \\
\hline
\end{tabular}

Source: developed by the authors taking into account (Pearse, 1985; Steiner, 2007)

reason for the differences in the life cycle stages of the industry, demand, technology, enterprise, product lays in the duration difference of the life cycles stages and the objects under study.

Many aspects of the life cycle analysis are determined by the peculiarities of the country or industry. There are industries where the product characteristics have been already formed by demand and practically unchanged, but products output technologies are rapidly changed due to the high level of competition. Sometimes, on the contrary, the technology used to produce one type of product continues to be used for the production of other product types related to a completely different field of activity (for example, many inventions in the field of chemistry are used further in medicine, food industry, etc.) (Schendel, 2002).

Demand can be satisfied by one type of product or service throughout all life cycle, in this case, the duration of demand life cycle and product lifecycle coincide. Demand during its life cycle can also be met by several types of products or services.

Comprehensive life cycle accounting of the industry, technology, enterprise, the product will improve the efficiency of the decisions made at all levels of enterprise management, as well as provide an opportunity to form an optimal strategic portfolio for the enterprise.

\section{Strategic planning methodology for life cycle stages}

To create the proper strategy for a particular product selection, it is necessary previously consider the trajectory of its development that is its life cycle. To do this, it is necessary to systematize the task solutions: to determine the set of key indicators, the range of their changes, and then consider all possible situations. 
For a rapid analysis of the product lifecycle, the external indicators are used: the product market growth rate, the product relative growth rate (in comparison with the growth rate of the entire market of the region or the country), the firm market share, the firm relative market share (compared with the share of leading competitor), and internal indicators: the dynamics of enterprise revenue by product, the dynamics of company profits by product, the dynamics of enterprise profitability by product, the dynamics of enterprise investment.

This is a standard list of factors used for portfolio analysis. Such a set is reasoned by its visibility, possibility of quantitative accounting over time, relative ease of getting. Other indexes for strategies adopting can be used at the qualitative level, for example, technological change, political, macroeconomic factors, etc.

For each indicator that describes the enterprise performance, the directions of change are taken: $\alpha-$ growth, const - constant or $\beta$ - decrease. The methodology involves a certain sequence of studying the product life cycle in retrospect and at the current moment, then the modelling and development of options for shortand long-term strategies implementation are made.
The method of enterprise product strategic planning at the stages of the life cycle involves the following algorithm, presented in Figure 1.1.

The construction of these models can be used to select a limited number of the product key parameters of the business entity. Further development of models assumes the probability tasks for the economic entity state, taking into account uncontrolled and controlled factors.

\section{Strategic planning under indefinite external environment: uncontrolled factors accounting}

All factors variety is divided into related, unrelated, controlled, and uncontrolled. There are several possible situations, combinations of strategies and uncontrolled factors, in which the effect is determined. Uncontrolled factors accounting is especially important for the evaluation of innovative and risk strategies or strategies adopted for a dynamic external environment.

The strategy assessment is determined on the basis of the project effect that implements the strategy under specific conditions. The definition of strategic project

I STAGE: TASK SETTING:

definition of key criteria for assessing the product life cycle, definition of the limits scope for the solvable problem, definition of parameters for developed models stability, forming models for analysis

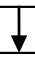

II STAGE: FORMING MODELS FOR ANALYSIS:

Model 1. Improvement of the company's competitive position in the market in retrospect.

Model 2. Stable company's competitive position in the market in retrospect.

Model 3. Deterioration of the competitive position in retrospect.

Model 4. Improvement of the company's competitive position in the market at the moment.

Model 5. Stable company's competitive position in the market at the moment.

Model 6. Deterioration of the competitive position at the moment.

III STAGE: SITUATIONS AND BASE STRATEGIES FOR EVERY MODEL FORMING:

Situation 1. Growing Market Capture Strategy (Leader follower strategy in the growing market).

Situation 2. Falling Market Capture Strategy (Leader follower strategy in the falling market).

Situation 3. Competitive Position Keeping Strategy on a Growing Market (Strategy of maintaining a competitive position in a growing market).

Situation 4. Competitive Position Keeping Strategy on a Falling Market (Strategy to maintaining a competitive position on the falling market).

Situation 5. Exit Strategy from Growing Market (Forecast of foreclosure from growing market).

Situation 6. Exit Strategy from Falling Market (Forecast of foreclosure from falling market).

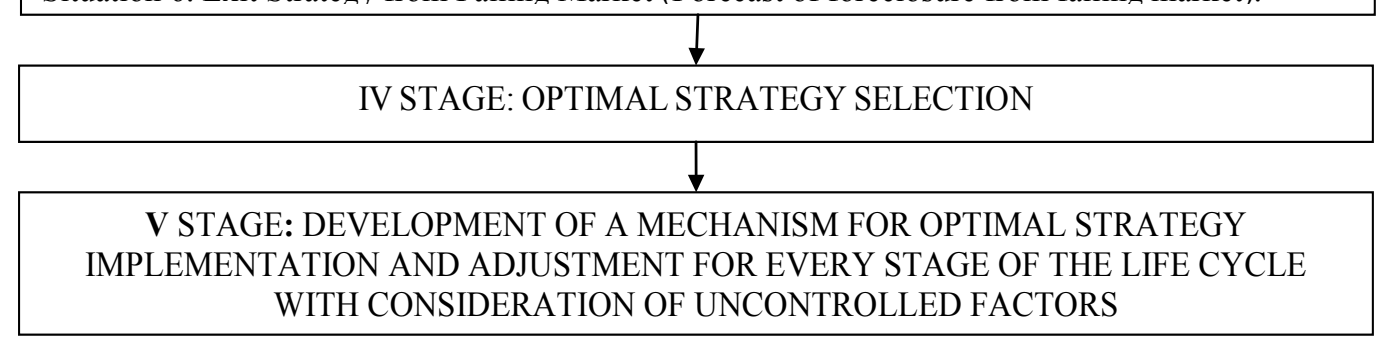

Fig. 1.1 The methodology of the enterprise product strategic planning at the life cycle stages (improved by the authors with taking into account (Mintzberg, 2008; Rumelt, 2014)) 
effect is based on the cash flows theory. The main feature of this theory is taking into account the time factor when the most effective project is selected. The need to record the time factor is reasoned by the fact that the useful results and costs, distributed in time, have different values. Investments (in particular, capital investments) and operating costs can be distributed in time in different ways.

Usually, it is assumed that the time factor should be taken into account when analysing projects with several years duration. However, under market conditions and unstable economy (transition economies), economic processes become much more dynamic. The uncertainty factor of the analysed processes significantly increases. The performance criteria for assessing the effectiveness of long-term projects are: economic effect (net present value), profitability index, internal rate of return, investment return period.

The risk and uncertainty factors get the first place under assessing qualitative criteria. The larger the investment project in terms of scale, time, territory, the more sophisticated technologies are used in it, the more unstable situation for the project implementation, the more important role the quality factors in the projects evaluation play. The importance of selection by quantitative criteria is reduced over the lack of reliable data and the possibility to predict them. Therefore, the need for selection and ranking based on quantitative criteria for mathematical accuracy of their calculation is reduced. With high instability, the unpredictability of a number of investment project features the necessity to take into account the uncertainty factor is set in the first place. This is especially important for the instability of the transition period of the domestic economy and the uncertainty of the environmental factors influence on the process of strategy implementation.

Use of the theory of optimal decision-making under uncertainty for the analysis of long-term projects allows transferring the qualitative factors into quantitative indicators, which can be used in the future to bring investment projects to the same kind and choose the best one. Based on the above, there is a need for a comprehensive consideration of time, uncertainty, and risk factors. To solve this problem, it is necessary to develop a methodology, principles, and methods for selecting effective projects taking into account these factors.

The methodology for strategic planning under indefinite environmental conditions taking into account the temporary factor is given below. The methodology includes:

1. Justification of the need to take into account time and uncertainty factors for assessing the strategy when using a profitable approach.

2. Mechanism of step-by-step adjustment and evaluation of the strategic decisions effectiveness.

3. The algorithm of complex estimation of strategies efficiency indicators taking into account factors of uncertainty and time.

Setting a task in conditions of uncertainty implies a multivariable solution for each time interval. This situation is the most realistic, especially for the unstable economy, transition economy, as well as for innovative projects, within which the strategy is implemented. In order to account all options for task solution, development of step-by-step adjustment mechanism and strategic decisions effectiveness evaluation are necessary. The methodology of multi-step processes under uncertainty has been considered in many works (Mintzberg, 2008; Pearse, 1985; Steiner, 2007). We will use a methodology for developing a mechanism for step-by-step adjustment and evaluation of the strategic decisions effectiveness under uncertainty (Table 1.5).

The latter task setting increases the requirements for a set of output data, a choice of different values of the effect at the same ratio of controlled and uncontrolled factors at different times, at different stages.

Table 1.4

The methodology of step-by-step adjustment and evaluation of the strategic decisions effectiveness under uncertainty

\begin{tabular}{|l|c|l|}
\hline \multicolumn{1}{|c|}{ Stage Features } & Stage Economic Expression & \multicolumn{1}{c|}{ Note } \\
\hline $\begin{array}{l}\text { 1. Indicators of effectiveness, } \\
\text { by which the strategy can be } \\
\text { evaluated, are determined }\end{array}$ & $E=\left\{E_{1}, E_{2}, \ldots, E_{k}\right\}$ & $\begin{array}{l}\text { Quantitative performance indicators include: additional profit, } \\
\text { revenue, or cost decrease by using a new business strategy in the } \\
\text { existing market; profit, capital investments profitability at strategy } \\
\text { commercialization on a new market, in a new product. }\end{array}$ \\
\hline $\begin{array}{l}\text { 2. Many factors that influence the } \\
\text { selected performance indicators } \\
\text { are formed }\end{array}$ & $F=\left\{F_{1}, F_{2}, \ldots, F_{f}\right\}$ & $\begin{array}{l}\text { It is chosen the principle of the decisions making optimality } \\
\text { depending on the conditions: nothing is known about the probability } \\
\text { of environmental factors; the probability of the environmental factors } \\
\text { influence is known; it is necessary to exclude any risk; risk is allowed; } \\
\text { the solution is implemented one or a small number times; the decision } \\
\text { is realized many times, etc. }\end{array}$ \\
\hline $\begin{array}{l}\text { 3. Horizon of calculation is } \\
\text { determined }\end{array}$ & $\begin{array}{l}\text { The maximum horizon of calculation for the strategy } \\
\text { implementation depends on the stability of the external } \\
\text { environment, industry, type of strategy. }\end{array}$ \\
\hline
\end{tabular}




\begin{tabular}{|c|c|c|}
\hline $\begin{array}{l}\text { 4. Calculation interval is } \\
\text { determined }\end{array}$ & $t=\left\{t_{1}, t_{2}, \ldots, t_{g}\right\}$ & $\begin{array}{l}\text { The interval or the calculation stage forms the part of the } \\
\text { calculation horizon. As a stage of calculation, year, quarter, month } \\
\text { can be adopted. The calculation stage can be chosen based on } \\
\text { the assumption that for this time period the impact and the set } \\
\text { of external and internal factors will remain unchanged. If it is } \\
\text { assumed that the influence and set of external and internal factors } \\
\text { will remain unchanged throughout the calculation horizon, then } \\
\text { the calculation stage equals the calculation horizon. }\end{array}$ \\
\hline $\begin{array}{l}\text { 5. The prevailing set of } \mathrm{F} \text { factors is } \\
\text { divided into controlled (managed) } \\
\text { and uncontrolled (unmanaged) } \\
\text { factors for each stage of } \\
\text { calculation }\end{array}$ & $\begin{array}{l}X^{g}=\left\{x_{1}, x_{2}, \ldots, x_{n}\right\}-\text { plenty of } \\
\text { controlled factors for the } g_{\mathrm{th}} \text { stage } \\
\quad \text { of calculation; } \\
X^{g}=\left\{y_{1}, y_{2}, \ldots, y_{m}\right\}-\text { plenty of } \\
\text { external environment factors for } \\
\quad \text { the } \mathrm{g}_{\mathrm{th}} \text { stage of calculation }\end{array}$ & $\begin{array}{l}\text { Controlled factors may be: products technological parameters, } \\
\text { products types, output volumes, etc. The factors of external } \\
\text { environment can be: products prices, demand volume, analogues } \\
\text { or substitutes appearance, new competitors' emergence, etc. The } \\
\text { influence of controlled and uncontrolled factors on performance } \\
\text { indicators is determined for each stage of calculation. }\end{array}$ \\
\hline $\begin{array}{l}\text { 6. Efficiency matrix for each stage } \\
\text { is formed }\end{array}$ & \multicolumn{2}{|c|}{$\left\|E_{1}\left(X^{1}, Y^{1}\right)\right\|,\left\|E_{2}\left(X^{2}, Y^{2}\right)\right\|, \ldots,\left\|E_{g}\left(X^{g}, Y^{g}\right)\right\|$} \\
\hline $\begin{array}{l}\text { 7. The plenty of choosing criteria } \\
\text { for optimal solution is formed }\end{array}$ & \multicolumn{2}{|c|}{$\begin{array}{l}\text { Principles and criteria for the optimal solution choosing in conditions of uncertainty: principles of } \\
\text { optimism, pessimism, guaranteed result, guaranteed losses, Savage, Bayes-Laplace criteria and others. } \\
\text { The most suitable criterion for each stage is determined. }\end{array}$} \\
\hline \multicolumn{3}{|c|}{ 8. The effect at each stage is determined, and its reduction to one moment of time is carried out. } \\
\hline \multicolumn{3}{|c|}{ 9. Strategy evaluation is carried out on the base of the obtained effect for the entire calculation horizon. } \\
\hline
\end{tabular}

Source: developed by the authors taking into account (Mintzberg, 2008; Pearse, 1985; Steiner, 2007)

However, the set of task solution allows: taking into account all the diversity of strategies and environmental factors at each stage of time; determining the effect for a number of years (stages) with a variety of participants' (decision-makers) behaviour.

\section{Conclusions}

The growing dynamics and uncertainty of external environment require the search for new management and decision-making methods that provide the enterprise (organization) with the ability to react quickly and with minimum expenses to the changes in the external environment. Continuous, unpredictable changes are an indispensable condition of the modern business.

Ups and downs of business activity at different levels of macro- and micro-environment within the organization are conditioned with various factors that should be taken into account in the management process. It is necessary to consider laws of systems development and life cycle at all management levels. The duration and cycle stages of each economic system depend on factors that can be classified into external and internal, managed and unmanaged. An issue of unmanaged factors forecasting and effective strategies developing for managing both the system life cycle and its elements life cycle arises.

There are many models and methods for managing the enterprise development: network planning, business planning, scheduling, financial planning, operations research, etc. They allow solving managerial tasks under the condition that the factors that influence the future of the enterprise are constant or can be predicted with some degree of probability. However, with the uncertainty of environmental factors that grows, the efficiency of these models and methods is reduced and additional methods that would allow solving tasks in conditions of uncertainty and would increase the strategic planning accuracy and validity are needed.

The application of life cycle models allow: reasonably forecast sales and plan a production program; determine the basic strategies at different stages of development; determine the sequence of stages of enterprise development; provide harmonious interaction of organizational features and factors of the external environment, which influence the process of organizational development.

The increase of organization development stability can be achieved by transforming the dynamic changes into the planned ones based on the application of effective prediction methods with taking into account the life cycle theory. In order to ensure the organization competitive advantage, it is necessary to take into account the interconnection of life cycles at all levels: industry, technology, enterprise, product.

The proposed methodology of strategic planning in the context of indefinite external environment taking into account the life cycle theory is systematized in this field and can be applied at the level of enterprises, organizations, industries, and regions in order to increase the validity of management decision-making in strategic planning.

The strategic planning methodology under conditions of indefinite external environment taking into account the life cycle theory includes: reasoning the necessity 
to consider factors of time and uncertainty in strategic planning; task setting in conditions of uncertainty; mechanism of step-by-step adjustment and evaluation of strategic decisions and strategies effectiveness in time; algorithm of complex estimation of strategy effectiveness indicators with taking into account uncertainty and time factors. Strategic planning is not characterized by temporary intervals but with a set of strategies, each of which is determined by ways of achieving the main enterprise objectives.

\section{References:}

Chaffee, E. (2011). Three models of strategy. Academy of Management Review, Vol. 10 (1), p. 89-98.

Chandler, A. D. (2015). Strategy and Structure. - Cambridge MIT Press, 480 p.

Higgins, J. M. (1993). Organizational Policy and Strategic Management. Text and Cases, 2-nd ed. - Chicago: The Dryden Press. $-237 \mathrm{p}$.

Mintzberg, H. (2008). The Strategy Process. - Boston: Brian Quinn, p. 5-13.

Kotler, Ph. (1991). Marketing Management: Analysis, Planning, Implementation, and Control. - NJ, Englewood Cliffs: Prentice-Hall International, Inc., 1991, 896 p.

Meier, G. M. (2015). Leading Issues in Economic Development. - Oxford University press, 672 p.

Rumelt, R. P. (2014). Strategy, Structure, and Economic Performance. - Boston : Harvard Business School Press, 2014. $-462 \mathrm{p}$.

Pearse, J. A. (1985). Strategic Management. 2-nd ed. - Homtwood III : Richard D.Irwin, 268 p.

Schendel, D. E. (2002). Business Policy or Strategic Management. A Broader View for an Emerging Discipline. Academy of Management Proceeding, $158 \mathrm{p}$.

Steiner, G. (2007). Management Policy and Strategic: Text, Reading and Gases - N.Y.: McMillan, 243 p. 